\title{
Valuing the commons: an international study on the recreational benefits of the Baltic Sea
}

\author{
Mikołaj Czajkowski ${ }^{1, *}$, Heini Ahtiainen ${ }^{2}$, Janne Artell2, Wiktor Budziński ${ }^{1}$, Berit Hasler ${ }^{3}$, \\ Linus Hasselström ${ }^{4}$, Jürgen Meyerhoff ${ }^{5}$, Tea Nõmmann ${ }^{6}$, Daiva Semeniene ${ }^{7}$, Tore Söderqvist ${ }^{4}$, \\ Heidi Tuhkanen ${ }^{7}$, Tuija Lankia ${ }^{2}$, Alf Vanags ${ }^{8}$, Marianne Zandersen ${ }^{3}$, Tomasz Żylicz ${ }^{1}$, Nick Hanley9
}

\begin{abstract}
:
The Baltic Sea provides benefits to all of the nine nations along its coastline, with some 85 million people living within the catchment area. Achieving improvements in water quality requires international cooperation. The likelihood of effective cooperation is known to depend on the distribution across countries of the benefits and costs of actions needed to improve water quality. In this paper, we estimate the benefits associated with recreational use of the Baltic Sea in current environmental conditions using a travel cost approach, based on data from a large, standardized survey of households in each of the 9 Baltic Sea states. Both the probability of engaging in recreation (participation) and the number of visits people make are modelled. A large variation in the number of trips and the extent of participation is found, along with large differences in current annual economic benefits from Baltic Sea recreation. The total annual recreation benefits are close to 15 billion EUR. Under a water quality improvement scenario, the proportional increases in benefits range from $7-18 \%$ of the current annual benefits across countries. Depending on how the costs of actions are distributed, this could imply difficulties in achieving more international cooperation to achieve such improvements.
\end{abstract}

\footnotetext{
${ }^{1}$ University of Warsaw, Faculty of Economic Sciences, Dluga 44/50, 00241 Warsaw, Poland

* Corresponding author: miq@wne.uw.edu.pl

${ }^{2}$ Natural Resources Institute Finland, Latokartanonkaari 9, 00790 Helsinki, Finland

${ }^{3}$ Environmental Social Science Group, Department of Environmental Science, Aarhus University, Frederiksborgvej 399, DK4000 Roskilde, Denmark

${ }^{4}$ Enveco Environmental Economics Consultancy, Måsholmstorget 3, SE127 48 Skärholmen, Sweden

${ }^{5}$ Institute for Landscape Architecture and Environmental Planning, Technische Universitat Berlin, Straße des 17. Juni 135, 10623 Berlin, Germany

${ }^{6}$ Stockholm Environment Institute Tallinn, Lai str 34, 10133 Tallinn, Estonia

${ }^{7}$ Center for Environmental Policy, Juozapavičiaus Str. 6/2, building D, LT09310 Vilnius, Lithuania

${ }^{8}$ Stockholm School of Economics in Riga, Strēlnieku iela 4a, LV1010 Riga, Latvia

${ }^{9}$ Department of Geography and Sustainable Development, University of St Andrews, Irvine Building, North Street, KY16 9AL, Fife, St Andrews, Scotland, UK
} 


\section{Highlights:}

- pollution has reduced important recreation benefits provided by the Baltic Sea

- a 9-country study of the economic value of recreational benefits is undertaken

- large variations in economic benefits per trip and per country are found

- benefits of an improvement in water quality are estimated for each country

- the distribution of benefits across countries could imply difficulties in reaching international agreements

Keywords: recreational value, the Baltic Sea, travel cost method, international public good

\section{Acknowledgements:}

We gratefully acknowledge the funding for the survey from the Swedish Environmental Protection Agency and the four Finnish Ministries (Ministry of Agriculture and Forestry, Ministry of Environment, Ministry of Transport and Communications and Ministry of Finance).We are also grateful for the support provided by the following projects/organizations: the research project Protection of the Baltic Sea: Benefits, costs and policy instruments (PROBAPS); the research alliance Integrated management of agriculture, fishery, environment and economy (IMAGE), funded by the Danish Research Council of strategic research; and the Baltic Nest Institute (BNI), funded by Aarhus University. The study was a subproject within the BalticSTERN research network, and we are grateful to the BalticSTERN Secretariat for support and coordination. The data collection was coordinated by Synovate Sweden. The first author acknowledges the support of the Polish Ministry of Science and Higher Education and the Foundation for Polish Science. We are grateful for prof. Anni Huhtala's substantial contribution in designing and conducting the study as well as comments which helped developing this manuscript. Any remaining errors are ours alone. 


\section{Introduction}

The Baltic Sea provides benefits to all of the nine nations along its coastline, with some 85 million people living within the catchment area (Ahtiainen et al., 2013). These benefits include direct use of the sea for recreation, non-use related values for individuals, transport and food production. The sea is an open access resource for neighboring nations, acting as a sink for nutrient pollution inputs from all states which has resulted in serious eutrophication problems (Hasler et al., 2014; Hyytiäinen et al., 2014; Wulff et al., 2014). Due to the fact that the nine littoral countries belong to multiple political jurisdictions (regional, national, and international), there is a degree of non-excludability in access to the Baltic Sea as a pollution sink and for fishing effort.

In the case of non-excludable international public goods, the overall well-being of parties can be enhanced by cooperative management. Despite the well-known strategic problems in incentivizing such cooperation (Barrett, 2006), multi-country cooperation to improve environmental management of the Baltic Sea has been progressively introduced, for example, by the Baltic Marine Environment Protection Commission (HELCOM). Whilst there are big differences between agreeing to sign such an international agreement and taking costly actions to help implement them, one important input fostering joint actions is the provision of information on the size of the potential economic benefits to each country from enhanced environmental quality (Hanley and Folmer, 1998; Finus, 2001). Such information can also help inform countries on the case for unilateral actions to improve the condition of global commons, even in the absence of international environmental agreements (Jeppesen and Andersen, 1998). Estimating aggregate recreation benefits is also important for national environmental accounting exercises (UNEP, 2012), whilst information on the benefits from changes in water quality is vital if social cost-benefit analysis is to be used to inform environmental management (Hanley and Barbier, 2009). ${ }^{1}$

The objectives of this paper are thus (i) to estimate and then compare the aggregate recreation benefits which are obtained from access to the Baltic Sea across all nine countries that border the sea; and (ii) to simulate the likely change in these benefits should water quality be improved. We provide these estimates by applying a method based on consumers' revealed preferences using the data obtained from a unique, standardized survey administered to large representative samples in each of the littoral countries of the Baltic Sea.

Many studies have been undertaken world-wide using both stated and revealed preference methods to estimate the economic benefits from improved coastal water quality, including studies which look

\footnotetext{
${ }^{1}$ For example, the European Union Marine Strategy Framework Directive (MSFD) requires cost-benefit analysis of measures to improve the state of marine waters.
} 
specifically at impacts on recreation. An overview of early work is provided in Hanley et al. (2003b). Recreation demand values for improvements in coastal water quality are also reported in a wide range of studies for UK (Hanley et al., 2003a), US (Poor and Breece, 2006), Australia (Rolfe and Gregg, 2012), South Africa (Nahman and Rigby, 2008) and many developing countries (Mathieu et al., 2003; Mwebaze and MacLeod, 2013). More broadly, Ahtiainen and Vanhatalo (2012) use meta-analysis to examine the benefits of improved water quality in Europe and Ghermandi and Nunes (2013) derive a global map of coastal recreation values, whilst Luisetti et al. (2014) discuss the problems in estimating and aggregating ecosystem service values in coastal environments. Paracchini et al. (2014) analyze, assess and discuss outdoor recreation in the EU as an ecosystem service value, including water related recreation.

Previous studies of water quality valuation in the Baltic Sea have mainly used stated preference methods (Markowska and Żylicz, 1999; Atkins et al., 2007; Eggert and Olsson, 2009; Kosenius, 2010; $\underline{\text { Ahtiainen et }}$ al. 2014). Existing travel cost studies of the value of water quality improvements to the Baltic Sea are few (Sandström, 1996; Soutukorva, 2005; Vesterinen et al., 2010), and there are no internationally comparable estimates of water recreation values.

Sandström (1996) and Soutukorva (2005) both apply the random utility model to estimate the benefits of improved water quality for Swedish seaside recreation and the Stockholm Archipelago respectively. Vesterinen et al. (2010) apply a travel cost method combined with water clarity data on lake and seashore recreation in Finland, focusing on individual's home municipalities. However, our paper is the first to provide comprehensive estimates of the recreational value of the Baltic Sea for all nine littoral countries. The unique characteristic of our study is that the data were collected using identical surveys in nine countries, thus providing an excellent opportunity for empirical analyses and cross-country comparisons of recreation values.

The paper is structured as follows. Section 2 introduces the modeling approaches used in the study. Section 3 describes design and implementation of the empirical study and data. The estimates of the recreational value and changes resulting from improved water quality are presented in Section 4 . The last section provides discussion and conclusions.

\section{Methods}

Economic valuation of recreation benefits using the travel cost method (TCM) ${ }^{2}$ is based on the simple observation that the benefits to individuals of outdoor recreation opportunities are revealed in their

\footnotetext{
${ }^{2}$ For a general overview of the method see Hanley and Barbier (2009).
} 
recreation behaviors - specifically, that they are willing to spend time and money to access a particular site to spend recreational time there (Hotelling, 1947). The TCM treats the number of trips an individual makes to a site as the quantity demanded, whilst the travel costs of the trip are treated as an approximation of the price paid for each visit. These assumptions, coupled with assumptions about the separability of the demand for recreation relative to the demand for other goods from which people derive utility, and weak complementarity between utility from trips and travel expenditures, result in a demand function of the following form (Freeman, 2003):

$$
r_{i}=f\left(p_{i}, \mathbf{z}_{i}\right)
$$

where $r_{i}$ is the number of trips taken by individual $i$ to a given site during a given time period, $p_{i}$ is the cost incurred in getting to a site (which usually consists of the cost of travel and opportunity cost of travel time, Czajkowski et al., forthcoming), and $\mathbf{z}_{i}$ is a vector of individual characteristics that are believed to influence the number of trips an individual takes.

Since $f(\cdot)$ represents the demand function, consumer $i$ 's surplus associated with a trip can be calculated as the following integral:

$$
C S_{i}=\int_{p_{i}^{0}}^{p_{i}^{*}} f\left(p_{i}, \mathbf{z}_{i}\right) d p_{i}
$$

where $p_{i}^{0}$ is the trip cost and $p_{i}^{\bullet}$ is the cost at which the number of trips by that individual goes to zero, also called a 'choke price'.

Since the number of visits an individual makes to a site is always an integer value, the standard approach for modeling recreation demand is to apply count data models, namely Poisson and Negative Binomial regressions or their generalizations. In the Poisson model, the probability that individual $i$ takes $k$ trips to the site is given by:

$$
P\left(y_{i}=k\right)=\frac{\lambda_{i}^{k}}{k !} e^{-\lambda_{i}}
$$

where $\lambda_{i}=\exp \left(\boldsymbol{\beta}^{\prime} \mathbf{x}_{i}\right)$ and $\mathbf{x}_{i}$ is a vector of individual characteristics. Even though Poisson regression assumes equi-dispersion, i.e., $E\left(y_{i}\right)=\operatorname{Var}\left(y_{i}\right)=\lambda_{i}$, uncommonly found in practice, this simple specification still produces consistent parameter estimates. Nonetheless, models that allow for under- or over-dispersion are often better fitted to the data. In a Negative Binomial regression the probability that $i$ 'th individual takes $k$ trips to the site is given by: 


$$
P\left(y_{i}=k\right)=\frac{\Gamma\left(\alpha^{-1}+k\right)}{\Gamma\left(\alpha^{-1}\right) \Gamma(k+1)}\left(\frac{\alpha^{-1}}{\alpha^{-1}+\lambda_{i}}\right)^{\alpha^{-1}}\left(\frac{\lambda_{i}}{\lambda_{i}+\alpha^{-1}}\right)^{k},
$$

where $\alpha$ is the over-dispersion parameter and $\lambda_{i}=E\left(y_{i}\right) \neq \operatorname{Var}\left(y_{i}\right)=\lambda_{i}+\alpha \lambda_{i}^{2}$.

Finally, another improvement in modelling recreation demand results from taking into account the share of respondents who take no trips to the site (Haab and McConnell, 1996). Instead of assuming that recreation enters every individual's utility function, i.e. interpreting no trips as a boundary solution of their utility maximization problem, we now allow for some individuals who even at a zero price would not consider a trip to the recreational site (so that a recreation trip to the Baltic Sea coast would not increase their utility). This is made possible by applying a Zero-Inflated Poisson or Negative Binomial models, where the probability that $i$ 'th individual takes $k$ trips is given as:

$$
P\left(y_{i}=k\right)=\left\{\begin{array}{lll}
\left(1-q\left(\boldsymbol{v}^{\prime} \boldsymbol{u}_{i}\right)\right) P_{1}\left(y_{i}=k\right)+q\left(\boldsymbol{v}^{\prime} \boldsymbol{u}_{i}\right) & \text { for } & k=0 \\
\left(1-q\left(\boldsymbol{v}^{\prime} \boldsymbol{u}_{i}\right)\right) P_{1}\left(y_{i}=k\right) & \text { for } & k>0
\end{array}\right. \text {. }
$$

In this specification $q\left(\boldsymbol{v}^{\prime} \boldsymbol{u}_{\boldsymbol{i}}\right)$ is the probability that individual $i$ is a non-participant (meaning that recreation at the site does not enter his utility function $)^{3}$ while $P_{1}\left(y_{i}=k\right)$ is the probability of taking $k>0$ trips to the site conditional on being a participant. For models presented above, consumer's surplus can be calculated using formula (2) by substituting $f\left(p_{i}, \mathbf{z}_{i}\right)$ for $E\left(y_{i} \mid p_{i}, \mathbf{z}_{i}\right)$. In Poisson and Negative Binomial models $E\left(y_{i}\right)=\lambda_{i}=\exp \left(\boldsymbol{\beta}^{\prime} \mathbf{x}_{i}\right)$ while in $\quad$ Zero Inflated models $E\left(y_{i} \mid p_{i}, \boldsymbol{z}_{\boldsymbol{i}}\right)=\left(1-q\left(\boldsymbol{\gamma}^{\prime} \boldsymbol{u}_{\boldsymbol{i}}\right)\right) \lambda_{i}=\left(1-q\left(\boldsymbol{\gamma}^{\prime} \boldsymbol{u}_{\boldsymbol{i}}\right)\right) \exp \left(\boldsymbol{\beta}^{\prime} \mathbf{x}_{i}\right)$. This leads to $C S_{i}=-\lambda_{i} / \beta_{T C}$ for Poisson and Negative Binomial and $C S_{i}=-\left(1-q\left(\boldsymbol{v}^{\prime} \boldsymbol{u}_{i}\right)\right) \lambda_{i} / \beta_{T C}$ for Zero Inflated models, where $\beta_{T C}$ is the estimated coefficient associated with the travel cost. ${ }^{4}$

${ }^{3} q(\cdot)$ is usually assumed to be a cdf of normal or logistic distribution; $\boldsymbol{u}_{\boldsymbol{i}}$ is a vector of individual characteristics. The first line of formula 5 is the sum of the probability of being a non-participant and the probability of being a participant and taking 0 trips.

${ }^{4}$ Consumer surplus resulting from a single trip to the site is $C S_{i}=-1 / \beta_{T C}$. 


\section{Description of the study and data}

The dataset used in this study was obtained from a survey that was conducted simultaneously in all nine countries around the Baltic Sea. ${ }^{5}$ For Russia only the inhabitants of the two administrative regions (Kaliningrad and Leningrad Oblast) on the coast of the Baltic Sea were surveyed. About 1,000 respondents in each country responded to the survey, leading to a sample of 9,127 observations (see Ahtiainen et al., 2013, for more details about the survey). ${ }^{6}$

The questionnaire was developed in English by an international research team and subsequently translated into national languages. ${ }^{7}$ The final version consisted of five modules: (1) an introduction, including a definition of the Baltic Sea; (2) questions about respondents' connection to and general use of the Baltic Sea and their place of residence; (3) details of their most recent visit to the sea; (4) attitudinal questions and (5) questions concerning socio-demographic characteristics. The interviews were conducted in AprilJune 2010 via telephone, or in Estonia, Latvia and Lithuania, via face-to-face interviews (because telephone surveys in these countries did not allow for a representative sample).

The outcome variable used in our study is the number of recreational trips to the Baltic Sea an individual has taken in the past 12 months $\left(\right.$ TRIPS). ${ }^{8}$ Both one-day and overnight trips are included, as well as different travel modes (car, public transport, walking, cycling). On average, some 55\% of respondents reported that they had taken no trips, which combined with a relatively high average number of trips for those who had visited the Baltic Sea at least once indicates the appropriateness of the Zero Inflated approach. This percentage of respondents with zero trips varied greatly across the nine countries, from $28 \%$ in Sweden to $93 \%$ in Russia. The travel distance facing each individual was approximated using information about the distance between the respondent's home (or other point of departure) and the location visited, both of which were reported by the respondent. The travel cost (TC) was calculated as a

\footnotetext{
${ }^{5}$ These countries are Denmark, Estonia, Finland, Germany, Latvia, Lithuania, Poland, Russia and Sweden.

${ }^{6}$ All the supplements to this manuscript are available online at czaj.org. Translation of the original questionnaire, dataset and software codes are provided under CC BY 4.0 license.

7 The translation of the questionnaire is available from the authors upon request or at: http://www.stockholmresilience.org/download/18.5004bd9712b572e3de6800014154/BalticSurvey bakgrundsrappor t webb.pdfS

${ }^{8}$ In the following analysis, we treated the Baltic Sea as a single site and estimated the corresponding welfare measures for the Baltic Sea as a whole. Although it is possible that the respondents who made more than one trip visited different sites, we only had data about their most recent trip and hence assumed that their all trips were the same. However, to take the seasonality of trip types into account, if respondents made trips in both April-September and October-March period, we randomized the period for which we asked about the details of their last trip.
} 
vehicle operating cost (which conservatively included petrol, oil and tyre use only ${ }^{9}$ ) and the opportunity cost of the respondent's leisure time ${ }^{10}$ for a return journey. ${ }^{11}$

Other variables used in recreation demand function included the $A G E$ of an individual, binary variables for their education level ( $E D U_{1}$ - primary education, $E D U_{2}$ - high school education, $E D U_{3}$ - vocational education, and $E D U_{4}$ - higher education), gender (MALE), having an occupation related to the Baltic Sea $(B O C C)$, number of children in household (HHKIDS) and household monthly net income (in thousands of EUR at PPP, HINC).

Finally, in order to take respondents' perceptions of Baltic Sea water quality into account we included an indicator variable $E N V B N$ based on respondents' answers to the following question: "In your opinion, what is, on average, the status of the environment in the XXXish part of the Baltic Sea?" where XXX referred to the relevant country, e.g. Danish. Answers were measured on a Likert scale from one to five, with the scale ranging from "very bad" to "very good".

Table 1 presents means and standard deviations (in square brackets) of the variables used in the analysis that follows. While the distribution of some variables is relatively similar across countries (e.g., $A G E$, $M A L E, H H K I D S, B O C C, E N V B N)$ other variables differ strongly. The mean number of recreational trips to the Baltic Sea coast within the previous 12 month period ranges from 1.1 (Poland) to over 6 (Sweden). ${ }^{12}$ There is also strong heterogeneity in the distribution of travel costs between countries. In Poland and Germany the mean travel cost is over 200 EUR per trip whereas in Denmark, Latvia and Estonia it is less than 50 EUR. This effect has two sources. Firstly, it is caused by the differences in country sizes - in Poland and Germany the mean reported distance travelled is over $500 \mathrm{~km}$, while in Estonia and Denmark it is less than $100 \mathrm{~km} .{ }^{13}$ Another source is the heterogeneity in the distribution of income between countries, and thus in the estimated cost of travel time. Mean monthly net household income varies from

\footnotetext{
${ }^{9}$ Average costs of petrol, oil and tires per country were calculated based on the guidelines provided by the AA insurance company (http://www.theaa.ie/AA/Motoring-advice/Cost-of-motoring.aspx). All prices were converted to EUR and corrected to take purchasing power parity (PPP) differences into account, using OECD data.

${ }^{10}$ The correct way of taking the opportunity cost of time has been debated in the literature, especially because is likely to be heterogeneous (Czajkowski et al., forthcoming) and endogenous (Amoako-Tuffour and MartínezEspiñeira, 2012). In this study we conservatively defined the opportunity cost of time as one-third of the average hourly earnings in each country - a practice adopted in several previous studies, for example, Gürlük and Rehber (2008), Egan et al. (2009) and Huhtala and Lankia (2012). Hourly earnings were estimated based on EUROSTAT or OECD household sources of income data.

${ }^{11}$ Note that although some respondents could have used other means of transport, we uniformly used the cost of a car journey as an approximation of the travel cost.

${ }^{12}$ Standard deviations of the numbers of TRIPS are much larger than means for each country which indicates the necessity of accounting for overdispersion in modelling.

${ }^{13}$ In addition to descriptive statistics for the entire sample, provided in Table 1, Supplement A (available online) presents descriptive statistics for respondents who made at least 1 recreational trip to the Baltic Sea.
} 
less than 750 EUR in Latvia and Lithuania, to over 3,200 EUR in Sweden. Finally, we note that the comparison of respondents' socio-demographic characteristics with relevant national statistics indicated that the sample characteristics were reasonably close to national averages, with a slight overrepresentation of female and older respondents in some countries.

\section{The results - recreational value of the Baltic Sea}

In order to calculate the annual recreational value of the Baltic Sea in its current condition (using consumers' surplus per visit estimates ${ }^{14}$ ) we apply a Zero-Inflated Negative Binomial model that allows the modeling of both the probability of non-participation (i.e., not being 'in a market' for the Baltic Sea recreation) and over-dispersion in distribution of the number of trips. We found that this model significantly outperformed simpler, more restrictive specifications. ${ }^{15}$ The results, along with the associated marginal effects ${ }^{16}$, are presented in Table 2.

All variables included in the model have a statistically significant effect on the dependent variable (number of TRIPS). The differences in country-specific constants indicate that there is a strong heterogeneity in terms of the average number of trips and the probability of non-participation, respectively. For example, respondents from coastal regions of Russia have on average the highest probability of non-participation, but at the same time they take more trips than respondents from most of

\footnotetext{
${ }^{14}$ Consumer surplus is the correct economic measure of the net benefit to an individual of being able to access a recreational site in a given condition. It is defined as the difference between the most an individual is willing to pay for recreation minus the costs of the recreational activity to them.

15 Specifically, we compared between different specifications of different count data models (such as Poisson, Negative Binomial of type 2 and Generalized Poisson of type 1, 2 and zero inflated models). We based our comparisons on Wald or LR test for nested models and the Vuong test for non-nested models. We also tried to fit more complicated models, such as the models with random parameters, but due to large differences the variables in our multi-country dataset could exhibit we usually encountered problems with convergence and hence unreliable results of such models.

${ }^{16}$ Marginal effects for the $i$ 'th respondent in the count regression model were calculated as partial derivative of the expected number of trips conditional on being a participant, i.e. $\partial \lambda_{i} / \partial \beta_{j}=\exp \left(\boldsymbol{\beta}^{\prime} \mathbf{x}_{i}\right) \beta_{j}$ if $j$-th variable was continuous, or $\left(\lambda_{i} \mid x_{i j}=1\right)-\left(\lambda_{i} \mid x_{i j}=0\right)$ were $x_{i j}$ is $j$-th variable for respondent $i$, in the case $j$ is a dummy variable. Analogous calculations were made for non-participation model $-\partial \Phi\left(\nu^{\prime} \mathbf{z}_{i}\right) / \partial \gamma_{j}=\phi\left(\nu^{\prime} \mathbf{z}_{i}\right) \gamma_{j}$ for continuous variables and $\left(\Phi\left(\boldsymbol{\gamma}^{\prime} \mathbf{z}_{i}\right) \mid z_{i j}=1\right)-\left(\Phi\left(\boldsymbol{\gamma}^{\prime} \mathbf{z}_{i}\right) \mid z_{i j}=0\right)$ for dummy variables, where $\Phi$ and $\phi$ are standard normal cumulative and probability functions respectively, since we used the probit model for estimating the participation equation. Marginal effects presented in Table 2 are averaged over entire sample. Standard errors for marginal effects were simulated as follows: firstly 10,000 draws from multivariate normal distribution were taken with mean equal to the estimates of parameters and covariance matrix equal to the inverse Hessian. Secondly for every drawn vector we calculated mean marginal effect in the sample. Reported standard errors are simply a standard deviation of these calculated means. Significance levels are calculated with assumption that simulated mean marginal effects follow normal distribution.
} 
the other countries (amongst those people who participate), ceteris paribus. ${ }^{17}$ For an illustrative comparison, in Estonia, people who do visit the Baltic Sea make fewer trips per year than in coastal Russia, but the probability of non-participation is also lower. The heterogeneity between countries can also be seen in the effect of travel cost on the number of trips. The demand functions differ significantly between countries - the demand is the most price-elastic in Latvia, and the least price-elastic in Russia. It is therefore reasonable to expect that the differences in per-visit consumer surplus estimates will be substantial.

The estimates of coefficients for the remaining variables show that having an occupation related to the Baltic Sea (BOCC), a higher income (HINC), although at a decreasing rate $\left(H I N C^{2}\right)$, being a $M A L E$ and a more favorable perception of the Baltic Sea water quality $(E N V B N)$ increase the expected number of trips. On the other hand, higher education levels, age, occupation related to the Baltic Sea, being a female respondent and the number of children decrease the probability that a respondent would be a nonparticipant for the Baltic Sea related recreation. As expected, respondents who consider the environment of the Baltic Sea as being of a higher quality are more likely to participate in recreation there. ${ }^{18}$

\subsection{Welfare measures for the status quo and the simulated improvement scenario}

We now turn to calculating the annual recreational value of the Baltic Sea in its current state based on the estimation results presented in the previous section. We then simulate the changes in this aggregate annual recreational value that would result from implementing a scenario of improvements in the perception of environmental quality of the Baltic Sea, and predict the changes in recreational patterns and the associated welfare measures in each country. Note that since travel behavior depends on perceived water quality rather than actual quality (Adamowicz et al., 2003; Hynes et al., 2008), we use changes in the former in

\footnotetext{
${ }^{17}$ In the Supplement B (available online) we present the results of models estimated for both regions of Russia entering separately. We find that the respondents from the Kaliningrad region are more likely to participate in Baltic Sea related recreation and they make much more trips than respondents from the Leningrad region, on average. However, the mean distance and travel cost are relatively similar while the consumer surplus per trip was not statistically different between these regions. The aggregated consumer surplus values are also relatively close, despite the Leningrad region being more populated. We interpret these results as an indication that respondents' preferences and the availability of coastal sites suitable for recreation can drive substantial differences between recreation patterns of consumers even within the same country.
}

${ }^{18}$ In addition, Supplement $C$ to the manuscript (available online) provides the results of the separate models for each country (negative binomial regression), to allow for additional between country comparisons of the model parameters. 
the simulations, rather than the latter. In practice, the two measures are likely to be spatially and temporally correlated with each other (Artell et al., 2013). ${ }^{19}$

The first row of Table 3 lists the adult population of each country. ${ }^{20,21}$ The second row reports the predicted probability of participation $\left(P_{p}\right)$ in the Baltic Sea recreation in each country. ${ }^{22,23}$ The probability is the lowest for the citizens of coastal regions of Russia (about 12\%) and the highest for the population of Denmark, Sweden, Estonia and Germany (over 95\%) followed by Poland, Latvia and Finland (over 90\%). The following four rows present the predicted probability of 0 trips $\left(p\left(y_{i}=0\right)\right)$ and the predicted average number of trips $\left(\lambda P_{p}\right)$, as well as the corresponding actual (observed) share of respondents who made no trip and the average number of trips in each country. We note that the predicted and actual values are relatively similar which may be an indication that our model is well-fitted.

Next, we report the average consumer surplus per trip in each country, using the trip cost as an indicator of the price. The consumer surplus differs from 28 EUR in Latvia and 31 EUR in Denmark, to almost 80 EUR in Germany, Estonia and Finland, and 98 EUR in Sweden. The highest per trip consumer surplus was observed for Russia, although due to relatively few Russian respondents reporting actually making a recreational trip to the Baltic Sea these results are associated with large confidence intervals. ${ }^{24}$

The next section of Table 3 presents aggregated welfare measures, i.e. the annual recreational value of the Baltic Sea for each country. These are a function of the population, participation rates, predicted number of trips and individual consumer surplus resulting from each trip. The results show that the current annual recreational benefits of the Baltic Sea are the largest for Germany (over 5.14 billion EUR) and Sweden (4.43 billion EUR) and followed by Poland (2.07 billion EUR), Finland (1.04 billion EUR) and Denmark

\footnotetext{
${ }^{19}$ We note that there is potential endogeneity between the perception of the environmental quality and whether individuals choose it for recreation. On the other hand, respondents who visit the Baltic Sea might have a more allowing perception to what a prohibitive quality may be, or may be visiting a place with a better-than-average quality of the environment. Finally, the subjective perception of the water quality can depend on the type of activity respondents participate in. Unfortunately, we did not have the necessary data to investigate the issue further in this study.

${ }^{20}$ For all countries except Russia coastal regions adult populations were calculated based on data from EUROSTAT. Adults were assumed to be over 18 years old. For Russia data about whole population were obtained from Russian Federal State Statistics Service.

${ }^{21}$ All data in the Table refers to the year our data was collected, i.e. 2012.

${ }^{22}$ The table presents the mean of respondent-specific participation probabilities rather than the participation probability for sample averages of explanatory variables.

${ }^{23}$ Note that it is possible to participate and still make 0 trips (i.e., being in a corner solution of the price being too high, rather than not being "in the market" at all). This potential demand may exhibit in trips made years apart.

${ }^{24}$ In addition, many of the Russian respondents made very distant trips, rather than trips to their domestic coast; their average length of stay at the coast was also the longest.
} 
(0.72 billion EUR). These results provide a valuable insight into the distribution of (recreational) benefits of the Baltic Sea. Interestingly, they show that recreational value of the Baltic Sea is not necessarily proportional to the population of a country.

Finally, we provide the results of a simulation scenario in which the (perception of) environmental quality of the Baltic Sea improves. This simulation is based on predicting the mean partial effect of changing the perceived water quality of the Baltic Sea. We calculated the partial effect for every individual in the sample as:

$$
\frac{\partial E\left(y_{i} \mid \mathbf{x}_{i}, \mathbf{u}_{i}\right)}{\partial E N V B N}=\left(1-\Phi\left(\boldsymbol{\gamma}^{\prime} \mathbf{u}_{i}\right)\right) \exp \left(\boldsymbol{\beta}^{\prime} \mathbf{x}_{i}\right) \beta_{E N V B N}-\phi\left(\boldsymbol{v}^{\prime} \mathbf{u}_{i}\right) \exp \left(\boldsymbol{\beta}^{\prime} \mathbf{x}_{i}\right) \gamma_{E N V B N}
$$

The model is non-linear and so the partial effect depends on all the other variables as well as on $E N V B N$ itself - for this reason we calculated the partial effect for each individual in the sample and averaged it over each country, as suggested by e.g., Greene (2011). The average partial effect may be interpreted as proxy for the change in the average expected number of trips to the Baltic Sea (presented in fifth row of Table 3.) when perception of its water quality increases by a value corresponding to one Likert scale unit. Of course this value may be a poor approximation of the partial effect for each individual as it is strongly non-linear, but it allows for a universal comparison of these effects between the countries.

The last two rows of Table 3 present the predicted total consumer surplus associated with the improvement scenario, as well as its relative change in comparison with the status quo. Such an improvement, associated with a one-step increase in the perceived water quality in the Baltic Sea, would result in the predicted annual recreational welfare increase of 1.96 billion EUR. This benefit would be unevenly distributed between the countries - the relative improvement varies from $7.47 \%$ to $18.14 \%$ between countries. Interestingly, it is the highest for the inhabitants of the coastal regions of Russia (who were also, on average, the most critical about the environmental condition of the Baltic Sea). In comparison with the stated preference studies of improved water quality in the Baltic Sea, the aggregate welfare estimate is somewhat lower. A recent contingent valuation study estimated the aggregate benefits of reduced eutrophication at 3.6 billion EUR per year in the nine countries (Ahtiainen et al., 2014). We note, however, that it is inherently difficult to compare benefits that result from different valuation methods or even across identical stated valuation methods if these do not value the same change in environmental quality or quantity. Contingent valuation studies often include both use and non-use values of a change in the quality or quantity of an environmental good whereas the travel cost method estimates only include use values for those who currently access the good. In addition, in the specification of the environmental change and the water quality measure differed (perceived environmental quality versus the actual eutrophication status measured on a quantitative scale). 


\section{Summary and conclusions}

This paper applies the individual travel cost method to estimate the annual recreational value of the Baltic Sea in its current condition for the populations in all nine littoral countries. We find that the total annual recreation benefits from the Baltic Sea are close to 15 billion EUR, of which over one third accrues to Germany (5.14 billion EUR), followed by Sweden (4.43 billion EUR), Poland (2.07 billion EUR), Finland (1.04 billion EUR), coastal regions of Russia (0.94 billion), Denmark (0.72 billion EUR), and the Baltic States - Lithuania, Estonia and Latvia (0.15, 0.11 and 0.19 billion EUR, respectively). These differences between the countries stem from differences in the average consumer surplus of a single recreational trip, how common and how frequent visiting the Baltic Sea in each country is, and the population of each country.

Looking at average consumer surplus of a single trip, we find an average benefit across the nine countries of approximately 85 EUR with above average values of access in coastal Russia and Sweden. The next highest per trip values can be found in Finland (81 EUR) and Germany (77 EUR). The average consumer surplus of a Baltic Sea trip in Poland is close to 71 EUR, while in Denmark it is 31 EUR. ${ }^{25}$ The Estonian single trip value is the highest of the Baltic States (78 EUR), followed by Lithuania (53 EUR) and Latvia (28 EUR). ${ }^{26}$

The differences in the average CS per trip can result from differences in respondents' preferences and cultural backgrounds, and differences in the availability of substitute sites (e.g., lakes and rivers, the North Sea for Germany and Denmark). ${ }^{27}$ It could also be revealing to account for the differences in the kinds of trips respondents made - since our goal here was to estimate mean welfare measures per country, we did not explicitly account for the differences in trip characteristics. Such an analysis could be an interesting extension - one could expect that the highly 'valuable' Russian, Swedish, Finnish, German, Polish or Estonian trips are different than e.g., Danish, Lithuanian or Latvian trips. Indeed, we found that while the

\footnotetext{
${ }^{25}$ Per trip CS reported for Denmark is relatively low, while the frequency of visits - amongst the highest. This is likely due to the short distance to the coast (the average includes numerous short trips, with lower per trip value).

${ }^{26}$ Similar differences between Estonia on the one hand, and Latvia and Lithuania on the other have been reported by Ahtiainen et al. (2014), where annual mean WTP per person for reducing eutrophication according to the Baltic Sea Action Plan in Estonia was at the same level as in Germany (24 EUR and 25 EUR respectively) and much larger than in the other Baltic States.

${ }^{27}$ While values for non-market goods may be sensitive to cultural variations, Hynes et al. (2013) found in a recent benefit transfer study that once differences in income levels were accounted for, the differences in cultural dimensions between study and policy sites actually had little impact on the magnitude of transfer estimates.
} 
average length of stay at the coast per Russian trip was close to 30 days, and the Germans, Poles and Estonians stayed at the coast for about 2 weeks on average, Danes, Latvians and Lithuanians stayed for less than a week. Additional differences are visible in the monthly distribution of trips and the kinds of recreational activities respondents were involved in (Ahtiainen et al., 2013). Moreover, we do not control for differences in on-site time costs, which is likely to vary across countries and between types of trip within each country. Since it is natural to expect a different consumer surplus from a 2-week stay at the coast in the summer compared with a 2-hour walk with a dog, the differences in the average CS per country may not be that surprising. They do, however, illustrate what the average welfare gain per trip is, and hence allow us to calculate the aggregated recreational benefits that the Baltic Sea coast provides to each country.

Our study also found substantial heterogeneity across countries with respect to the willingness to undertake trips to the Baltic Sea coast. At one extreme, 93\% of the coastal Russian sample report having made no trips during the previous 12 months, and at the other extreme, only about $29 \%$ of Swedish respondents reported not having been to the coast during the past year. We also find significant differences within one country such as Russia, where respondents from the Kaliningrad region undertake significantly many more trips per year than in the Saint Petersburg region, although travel costs, travel distance (to the nearest shore) and consumer surplus per trip are similar. This indicates that respondents' preferences and availability of coastal sites suitable for recreation are important determinants of the value of access to the Baltic Sea.

Although some people report not having made a trip during the past 12 months, some may still be willing to undertake trips in the future, whereas others may never wish to visit the Baltic Sea, for example because they prefer other forms of recreation. We found that explicitly accounting for consumers' nonparticipation significantly improved the robustness of the statistical approach used to model recreational values. Age, being a female, a lower education level, having children and an occupation related to the Baltic Sea all significantly increase the probability of being 'in the market' for the Baltic Sea recreation. On the other hand, the trip frequency is increased with higher income, being a male and (understandably) holding a more favorable perception of water quality of the sea. Similar effects have also been found in the Finnish travel cost study by Vesterinen et al. (2010).

In addition to providing an overview of the current distribution of recreation benefits, we conducted a simulation indicating a substantial increase in benefits (1.96 billion EUR per year) if the perceived water quality was improved. In absolute terms, largest gains are found in Germany, Sweden, coastal Russia and Poland, while the relative change in consumer surplus is largest in coastal Russia. Such results on the 
benefits of improved water quality can be a valuable input into cost-benefit analyses which deal with the distribution of costs and benefits in the Baltic Sea countries (see e.g., Elofsson, 2010; Ahlvik et al., 2014; Hasler et al., 2014; Hyytiäinen et al., 2014; Wulff et al., 2014). ${ }^{28}$

In our study, the welfare change is estimated for a perceived increase in water quality. Although using perceived water quality change is appropriate as people's behavior is based on perceptions, we acknowledge that it might be difficult to link this to actual changes in water quality. Artell et al. (2013) have shown, however, that at least in the case of Finland, roughly half of the respondents assessed water quality similarly to the scientifically measured quality. We note that additional research on the linkage between the subjective perceptions and ecologically based scientific measurements and targets of water quality is needed across different cultural backgrounds.

We began this paper with the observation that the Baltic Sea has aspects of a common property resource. Pollution inputs from individual countries reduce utility for residents of many nations, and there is no legal basis for restricting the inputs of countries from multiple jurisdictions. This, along with variations in the costs of actions to reduce nutrient pollution, implies a need for international cooperation. Barrett (2006) has noted that one factor which determines the likelihood of effective international agreements on actions to improve common property resources (including the global commons) is how the benefits and costs of actions are distributed across potential collaborators. International cooperation between the nine littoral countries to improve water quality in the Baltic Sea is already ongoing through the Baltic Sea Action Plan under HELCOM. However, the initiatives of the Action Plan are not based on the distribution of costs and benefits of enhancing water quality across the countries. Our analysis shows that the benefits of water quality improvements are very different across countries. Hence, depending on how the costs of actions to reduce nutrient pollution are distributed across the Baltic states, there may be significant barriers to achieving further international agreements on cleaning up the Baltic Sea.

\footnotetext{
28 Additionally, encouraged by one of the reviewers of this paper, we conducted a similar simulation while controlling for the differences in the average distance to the coast in each country. These results are available in Supplement D (available online). We found that controlling for distance differences leads to much higher benefits in Germany, Poland and coastal Russia, while reducing the benefits in all the other countries, with Sweden, Denmark and Finland population being the best off by their populations living close to the coast.
} 


\section{References}

Adamowicz, W., Swait, J., Boxall, P. C., Louviere, J., and Williams, M., 2003. Perception versus objective measures of environmental quality in combined revealed and stated preference models of environmental valuation. In: The New Economics of Outdoor Recreation, N. Hanley, W. D. Shaw, and R. E. Wright, eds., Edward Elgar Pub.

Ahlvik, L., Ekholm, P., Hyytiäinen, K., and Pitkänen, H., 2014. An economic-ecological model to evaluate impacts of nutrient abatement in the Baltic Sea. Environmental Modelling \& Software, 55(0):164-175.

Ahtiainen, H., Artell, J., Czajkowski, M., Hasler, B., Hasselström, L., Huhtala, A., Meyerhoff, J., Smart, J. C. R., Söderqvist, T., Alemu, M. H., Angeli, D., Dahlbo, K., Fleming-Lehtinen, V., Hyytiäinen, K., Karlõševa, A., Khaleeva, Y., Maar, M., Martinsen, L., Nõmmann, T., Pakalniete, K., Oskolokaite, I., and Semeniene, D., 2014. Benefits of meeting nutrient reduction targets for the Baltic Sea - a contingent valuation study in the nine coastal states. Journal of Environmental Economics and Policy:1-28.

Ahtiainen, H., Artell, J., Czajkowski, M., Hasler, B., Hasselström, L., Hyytiäinen, K., Meyerhoff, J., Smart, J., Söderqvist, T., Zimmer, K., Khaleeva, J., Rastrigina, O., and Tuhkanen, H., 2013. Public preferences regarding use and condition of the Baltic Sea - an international comparison informing marine policy. Marine Policy, 42:20-30.

Ahtiainen, H., and Vanhatalo, J., 2012. The value of reducing eutrophication in European marine areas - A Bayesian meta-analysis. Ecological Economics, 83(0):1-10.

Amoako-Tuffour, J., and Martínez-Espiñeira, R., 2012. Leisure and the Net Opportunity Cost of Travel Time in Recreation Demand Analysis: An Application to Gros Morne National Park. Journal of Applied Economics, 15(1):25-49.

Artell, J., Ahtiainen, H., and Pouta, E., 2013. Subjective vs. objective measures in the valuation of water quality. Journal of Environmental Management, 130(0):288-296.

Atkins, J. P., Burdon, D., and Allen, J. H., 2007. An application of contingent valuation and decision tree analysis to water quality improvements. Marine Pollution Bulletin, 55(1012):591-602.

Barrett, S., 2006. Environment and Statecraft: The Strategy of Environmental Treaty-Making. Oxford University Press.

Czajkowski, M., Giergiczny, M., Kronenberg, J., and Englin, J., forthcoming. The Individual Travel Cost Method with Consumer-Specific Values of Travel Time Savings.

Egan, K. J., Herriges, J. A., Kling, C. L., and Downing, J. A., 2009. Valuing Water Quality as a Function of Water Quality Measures. American Journal of Agricultural Economics, 91(1):106-123.

Eggert, H., and Olsson, B., 2009. Valuing multi-attribute marine water quality. Marine Policy, 33(2):201-206.

Elofsson, K., 2010. The Costs of Meeting the Environmental Objectives for the Baltic Sea: A Review of the Literature. $A M B I O, 39(1): 49-58$.

Finus, M. (2001) Game Theory and International Environmental Cooperation. Cheltenham: Edward Elgar .

Freeman, A. M., 2003. The Measurement of Environmental and Resource Values: Theory and Methods. 2 Ed., Resources for the Future Inc., Washington, DC.

Ghermandi, A., and Nunes, P. A. L. D., 2013. A global map of coastal recreation values: Results from a spatially explicit meta-analysis. Ecological Economics, 86(0):1-15.

Greene, W. H., 2011. Econometric Analysis. 7 Ed., Prentice Hall, Upper Saddle River, NJ. 
Gürlük, S., and Rehber, E., 2008. A travel cost study to estimate recreational value for a bird refuge at Lake Manyas, Turkey. Journal of Environmental Management, 88(4):13501360.

Haab, T. C., and McConnell, K. E., 1996. Count Data Models and the Problem of Zeros in Recreation Demand Analysis. American Journal of Agricultural Economics, 78(1):89102.

Hanley, N., and Barbier, E. B., 2009. Pricing Nature. Cost-Benefit Analysis and Environmental Policy. Edward Elgar, Edward Elgar, Cheltenham, UK and Northampton, MA, USA.

Hanley, N., Bell, D., and Alvarez-Farizo, B., 2003a. Valuing the Benefits of Coastal Water Quality Improvements Using Contingent and Real Behaviour. Environmental and Resource Economics, 24(3):273-285.

Hanley, N., Shaw, W. D., and Wright, R. E., eds. 2003b. The New Economics of Outdoor Recreation. Edward Elgar Pub.

Hanley N. and Folmer H. (1998) Game Theory and the Environment. Cheltenham: Edward Elgar.

Hasler, B., Smart, J. C. R., Fonnesbech-Wulff, A., Andersen, H. E., Thodsen, H., Mathiesen, G. B., Smedberg, E., Göke, C., Czajkowski, M., Was, A., Elofsson, K., Humborg, C., Wolfsberg, A., and Wulff, F., 2014. Hydro-economic modelling of cost-effective transboundary water quality management in the Baltic Sea. Water Resources and Economics, 5:1-23.

Hotelling, H., 1947. Letter to the National Park Service. Reprinted in An Economic Study of theMonetary Evaluation of Recreation in the National Parks (1949). US Department of the Interior, National Park Service and Recreational Planning Division, Washington, DC.

Huhtala, A., and Lankia, T., 2012. Valuation of trips to second homes: do environmental attributes matter? Journal of Environmental Planning and Management, 55(6):733-752.

Hynes, S., Hanley, N., and Scarpa, R., 2008. Effects on Welfare Measures of Alternative Means of Accounting for Preference Heterogeneity in Recreational Demand Models American Journal of Agricultural Economics, 90(4):1011-1027.

Hynes, S., Norton, D., and Hanley, N., 2013. Adjusting for Cultural Differences in International Benefit Transfer. Environmental and Resource Economics, 56(4):499-519.

Hyytiäinen, K., Ahlvik, L., Ahtiainen, H., Artell, J., Huhtala, A., and Dahlbo, K., 2014. Policy Goals for Improved Water Quality in the Baltic Sea: When do the Benefits Outweigh the Costs? Environmental and Resource Economics:1-25.

Jeppesen T. and Andersen P. (1998) "Commitment and fairness in environmental games" in Hanley N. and Folmer H. (1998) Game Theory and the Environment. Cheltenham: Edward Elgar, pages 65-83.

Kosenius, A.-K., 2010. Heterogeneous preferences for water quality attributes: The Case of eutrophication in the Gulf of Finland, the Baltic Sea. Ecological Economics, 69(3):528538.

Luisetti, T., Turner, R. K., Jickells, T., Andrews, J., Elliott, M., Schaafsma, M., Beaumont, N., Malcolm, S., Burdon, D., Adams, C., and Watts, W., 2014. Coastal Zone Ecosystem Services: From science to values and decision making; a case study. Science of the Total Environment, 493(0):682-693.

Markowska, A., and Żylicz, T., 1999. Costing an International Public Good: The Case of the Baltic Sea. Ecological Economics, 30:301-316.

Mathieu, L. F., Langford, I. H., and Kenyon, W., 2003. Valuing marine parks in a developing country: a case study of the Seychelles. Environment and Development Economics, 8(02):373-390. 
Mwebaze, P., and MacLeod, A., 2013. Valuing marine parks in a small island developing state: a travel cost analysis in Seychelles. Environment and Development Economics, 18(04):405426.

Nahman, A., and Rigby, D., 2008. VALUING BLUE FLAG STATUS AND ESTUARINE WATER QUALITY IN MARGATE, SOUTH AFRICA1. South African Journal of Economics, 76(4):721-737.

Paracchini, M. L., Zulian, G., Kopperoinen, L., Maes, J., Schägner, J. P., Termansen, M., Zandersen, M., Perez-Soba, M., Scholefield, P. A., and Bidoglio, G., 2014. Mapping cultural ecosystem services: A framework to assess the potential for outdoor recreation across the EU. Ecological Indicators, 45(0):371-385.

Poor, P. J., and Breece, M., 2006. The contingent behavior of charter fishing participants on the Chesapeake Bay: Welfare estimates associated with water quality improvements. Journal of Environmental Planning and Management, 49(2):265-278.

Rolfe, J., and Gregg, D., 2012. Valuing beach recreation across a regional area: The Great Barrier Reef in Australia. Ocean \& Coastal Management, 69(0):282-290.

Sandström, M., 1996. Recreational Benefits from Improved Water Quality: A Random Utility Model of Swedish Seaside Recreation. Working Paper No. 121, Stockholm School of Economics, The Economic Research Institute.

Soutukorva, A., 2005. The value of improved water quality. A Random Utility Model of Recreation on the Stockholm Archipelago. Beijer International Institute of Ecological Economics, The Royal Swedish Academy of Sciences.

UNEP, 2012. Environmental Accounting of National Economic Systems. United Nations Environment Programme.

Vesterinen, J., Pouta, E., Huhtala, A., and Neuvonen, M., 2010. Impacts of changes in water quality on recreation behavior and benefits in Finland. Journal of Environmental Management, 91(4):984-994.

Wulff, F., Humborg, C., Andersen, H. E., Blicher-Mathiesen, G., Czajkowski, M., Elofsson, K., Fonnesbech-Wulff, A., Hasler, B., Hong, B., Jansons, V., Mörth, C.-M., Smart, J. C. R., Smedberg, E., Stålnacke, P., Swaney, D. P., Thodsen, H., Was, A., and Żylicz, T., 2014. Reduction of Baltic Sea Nutrient Inputs and Allocation of Abatement Costs Within the Baltic Sea Catchment. AMBIO: A Journal of the Human Environment, 43(1):11-25. 
Table 1. Descriptive statistics of the explanatory variables (standard deviations in square brackets)

\begin{tabular}{|c|c|c|c|c|c|c|c|c|c|}
\hline & Denmark & Estonia & Finland & Germany & Latvia & Lithuania & Poland & $\begin{array}{c}\text { Russia } \\
\text { (coastal) }\end{array}$ & Sweden \\
\hline TRIPS & 5.96 & 1.82 & 3.95 & 1.21 & 2.64 & 1.66 & 1.11 & 0.46 & 6.42 \\
\hline (number) & {$[15.44]$} & {$[5.62]$} & {$[19.78]$} & [10.69] & {$[7.16]$} & {$[5.77]$} & {$[8.45]$} & [2.44] & {$[13.13]$} \\
\hline$D I S T$ & 93.55 & 89.77 & 171.53 & 565.13 & 115.21 & 247.06 & 461.21 & 397.00 & 135.62 \\
\hline (distance, $\mathrm{km}$ ) & {$[96.12]$} & {$[87.49]$} & [149.85] & [248.90] & [100.08] & [113.57] & [215.43] & [226.72] & [146.47] \\
\hline TIME & 2.89 & 2.65 & 5.71 & 7.13 & 2.78 & 3.38 & 7.93 & 5.05 & 4.80 \\
\hline (travel time, hours) & {$[3.11]$} & {$[2.73]$} & {$[10.29]$} & {$[3.01]$} & {$[2.46]$} & {$[1.51]$} & {$[3.86]$} & {$[3.03]$} & {$[5.30]$} \\
\hline$T R I P S=0$ & 0.37 & 0.40 & 0.49 & 0.75 & 0.53 & 0.65 & 0.69 & 0.93 & 0.28 \\
\hline (share of respondents) & {$[0.48]$} & {$[0.49]$} & {$[0.50]$} & {$[0.42]$} & {$[0.49]$} & {$[0.47]$} & {$[0.46]$} & {$[0.25]$} & {$[0.45]$} \\
\hline$T C$ & 37.45 & 38.34 & 81.81 & 203.5 & 49.70 & 107.1 & 201.8 & 136.2 & 63.74 \\
\hline (travel cost, EUR) & [37.89] & {$[37.28]$} & {$[92.06]$} & [87.61] & {$[43.18]$} & {$[49.00]$} & {$[93.84]$} & {$[77.53]$} & {$[64.41]$} \\
\hline$T C_{-} k m$ & 18.66 & 29.33 & 39.59 & 141.72 & 41.71 & 98.17 & 176.61 & 113.41 & 28.64 \\
\hline $\begin{array}{c}\text { (vehicle operating cost, } \\
\text { EUR) }\end{array}$ & {$[19.17]$} & {$[28.59]$} & {$[34.59]$} & {$[62.44]$} & {$[36.23]$} & {$[45.13]$} & {$[82.52]$} & {$[64.79]$} & {$[30.93]$} \\
\hline TC_time & 18.79 & 9.01 & 42.21 & 61.81 & 7.99 & 8.95 & 25.15 & 22.80 & 35.09 \\
\hline (opportunity cost, EUR) & {$[20.26]$} & {$[9.30]$} & {$[76.10]$} & {$[26.07]$} & {$[7.07]$} & {$[4.00]$} & {$[12.24]$} & {$[13.71]$} & {$[38.74]$} \\
\hline$A G E$ & 51.30 & 44.62 & 50.84 & 48.82 & 44.64 & 48.04 & 50.65 & 39.75 & 54.28 \\
\hline (years) & {$[15.46]$} & {$[16.57]$} & {$[17.16]$} & [14.84] & {$[16.82]$} & {$[17.92]$} & {$[15.90]$} & {$[13.50]$} & {$[17.69]$} \\
\hline$E D U_{1}$ & 0.13 & 0.16 & 0.17 & 0.26 & 0.19 & 0.26 & 0.05 & 0.01 & 0.24 \\
\hline $\begin{array}{c}\text { (share - compulsory } \\
\text { school) }\end{array}$ & {$[0.34]$} & {$[0.36]$} & {$[0.38]$} & {$[0.44]$} & {$[0.39]$} & {$[0.43]$} & {$[0.22]$} & {$[0.10]$} & {$[0.42]$} \\
\hline$E D U_{2}$ & 0.08 & 0.04 & 0.35 & 0.18 & 0.23 & 0.27 & 0.53 & 0.24 & 0.25 \\
\hline (share - high school) & {$[0.27]$} & {$[0.21]$} & {$[0.47]$} & {$[0.39]$} & {$[0.42]$} & {$[0.44]$} & {$[0.49]$} & {$[0.42]$} & {$[0.43]$} \\
\hline$E D U_{3}$ & 0.22 & 0.58 & 0.16 & 0.47 & 0.33 & 0.26 & 0.04 & 0.23 & 0.13 \\
\hline $\begin{array}{c}\text { (share }- \text { vocational } \\
\text { education) }\end{array}$ & {$[0.41]$} & {$[0.49]$} & {$[0.36]$} & [0.49] & {$[0.47]$} & {$[0.44]$} & {$[0.21]$} & {$[0.42]$} & {$[0.33]$} \\
\hline$E D U_{4}$ & 0.55 & 0.20 & 0.31 & 0.07 & 0.22 & 0.19 & 0.36 & 0.50 & 0.37 \\
\hline $\begin{array}{c}\text { (share - university } \\
\text { education) }\end{array}$ & {$[0.49]$} & {$[0.40]$} & {$[0.46]$} & {$[0.26]$} & {$[0.41]$} & {$[0.39]$} & {$[0.48]$} & {$[0.50]$} & {$[0.48]$} \\
\hline MALE & 0.51 & 0.43 & 0.52 & 0.49 & 0.52 & 0.46 & 0.68 & 0.49 & 0.55 \\
\hline (share) & {$[0.49]$} & {$[0.49]$} & {$[0.49]$} & {$[0.50]$} & {$[0.49]$} & [0.49] & {$[0.46]$} & {$[0.50]$} & {$[0.49]$} \\
\hline BOCC & 0.06 & 0.08 & 0.08 & 0.04 & 0.06 & 0.03 & 0.06 & 0.06 & 0.08 \\
\hline $\begin{array}{c}\text { (share of respondents } \\
\text { having an occupation } \\
\text { related to the Baltic Sea) }\end{array}$ & {$[0.25]$} & {$[0.28]$} & {$[0.27]$} & {$[0.20]$} & {$[0.24]$} & {$[0.17]$} & {$[0.24]$} & {$[0.24]$} & {$[0.27]$} \\
\hline HHKIDS & 0.68 & 0.53 & 0.62 & 0.49 & 0.57 & 0.47 & 0.54 & 0.89 & 0.50 \\
\hline $\begin{array}{c}\text { (number of kids in the } \\
\text { household) }\end{array}$ & {$[1.02]$} & {$[0.81]$} & {$[1.15]$} & {$[0.88]$} & {$[0.95]$} & {$[0.81]$} & {$[0.91]$} & {$[0.88]$} & {$[0.88]$} \\
\hline HINC & 2.43 & 1.24 & 2.24 & 2.16 & 0.73 & 0.68 & 1.27 & 1.25 & 3.22 \\
\hline $\begin{array}{c}\text { (household income } \\
\text { EUR/month ) }\end{array}$ & {$[1.05]$} & {$[0.67]$} & {$[1.01]$} & [0.99] & {$[0.33]$} & {$[0.36]$} & {$[0.91]$} & {$[0.68]$} & [1.31] \\
\hline$E N V B N$ & 3.39 & 2.94 & 2.79 & 3.62 & 3.20 & 2.94 & 3.18 & 2.61 & 3.11 \\
\hline $\begin{array}{l}\text { (perception of water } \\
\text { quality, mean score) }\end{array}$ & {$[0.84]$} & {$[0.69]$} & {$[0.81]$} & {$[0.82]$} & {$[0.82]$} & {$[0.86]$} & [1.44] & [1.02] & {$[0.82]$} \\
\hline Observations & 982 & 970 & 996 & 995 & 1051 & 1024 & 1004 & 936 & 935 \\
\hline
\end{tabular}


Table 2. Estimation results of the zero inflated negative binomial model of the annual number of recreational trips to the Baltic Sea coast

\begin{tabular}{|c|c|c|c|c|c|c|c|}
\hline \multirow[b]{2}{*}{ Variable } & \multicolumn{3}{|c|}{$\begin{array}{l}\text { Count regression - } \\
\text { negative binomial }\end{array}$} & \multicolumn{4}{|c|}{$\begin{array}{c}\text { Non-participation regression - } \\
\text { probit } \\
\end{array}$} \\
\hline & $\begin{array}{c}\text { coefficient } \\
\text { (s.e.) }\end{array}$ & $\begin{array}{c}\text { marginal eff } \\
\text { (s.e.) } \\
\end{array}$ & & $\begin{array}{c}\text { coefficient } \\
\text { (s.e.) }\end{array}$ & & $\begin{array}{c}\text { marginal effec } \\
\text { (s.e.) } \\
\end{array}$ & \\
\hline Denmark & $\begin{array}{l}1.9878 * * * \\
(0.0706)\end{array}$ & $\begin{array}{l}15.5317 \\
(1.3044)\end{array}$ & $* * *$ & $\begin{array}{r}-2.8536 \\
(0.3777)\end{array}$ & $* * *$ & $\begin{array}{r}-0.1913 \\
(0.0761)\end{array}$ & $* *$ \\
\hline Estonia & $\begin{array}{l}0.7751 * * * \\
(0.0614)\end{array}$ & $\begin{array}{r}3.3723 \\
(0.3905)\end{array}$ & $* * *$ & $\begin{array}{l}-1.6212 \\
(0.3477)\end{array}$ & $* * *$ & $\begin{array}{l}-0.1364 \\
(0.0508)\end{array}$ & $* * *$ \\
\hline Finland & $\begin{array}{l}1.5547 * * * \\
(0.0571)\end{array}$ & $\begin{array}{l}10.0336 \\
(0.7412)\end{array}$ & $* * *$ & $\begin{array}{l}-1.7009 \\
(0.2927)\end{array}$ & $* * *$ & $\begin{array}{l}-0.1403 \\
(0.0473)\end{array}$ & $* * *$ \\
\hline Germany & $\begin{array}{l}1.5764 * * * \\
(0.0779)\end{array}$ & $\begin{array}{l}11.1152 \\
(1.0924)\end{array}$ & $* * *$ & $\begin{array}{l}-1.8427 \\
(0.3755)\end{array}$ & $* * *$ & $\begin{array}{l}-0.1524 \\
(0.0553)\end{array}$ & $* * *$ \\
\hline Latvia & $\begin{array}{l}1.7411 * * * \\
(0.0796)\end{array}$ & $\begin{array}{r}12.9051 \\
(1.2955)\end{array}$ & $* * *$ & $\begin{array}{l}-1.2584 \\
(0.3186)\end{array}$ & $* * *$ & $\begin{array}{l}-0.1113 \\
(0.0419)\end{array}$ & $* * *$ \\
\hline Lithuania & $\begin{array}{l}2.0602 * * * \\
(0.1252)\end{array}$ & $\begin{array}{l}19.2002 \\
(2.7941)\end{array}$ & $* * *$ & $\begin{array}{r}-0.5540 \\
(0.2893)\end{array}$ & $*$ & $\begin{array}{c}-0.0511 \\
(0.0303)\end{array}$ & $*$ \\
\hline Poland & $\begin{array}{l}1.6054 * * * \\
(0.0638)\end{array}$ & $\begin{array}{l}11.5342 \\
(0.9523)\end{array}$ & $* * *$ & $\begin{array}{r}-1.5749 \\
(0.3316)\end{array}$ & $* * *$ & $\begin{array}{c}-0.1341 \\
(0.0480)\end{array}$ & $* * *$ \\
\hline Russia & $\begin{array}{l}1.3829 * * * \\
(0.2729)\end{array}$ & $\begin{array}{r}8.5203 \\
(3.0730)\end{array}$ & $* * *$ & $\begin{array}{r}2.5233 \\
(0.2619)\end{array}$ & $* * *$ & $\begin{array}{r}0.4506 \\
(0.0961)\end{array}$ & $* * *$ \\
\hline Sweden & $\begin{array}{l}1.8214 * * * \\
(0.0895)\end{array}$ & $\begin{array}{l}12.6051 \\
(1.3395)\end{array}$ & $* * *$ & $\begin{array}{c}-3.1023 \\
(0.3678)\end{array}$ & $* * *$ & $\begin{array}{c}-0.2011 \\
(0.0754)\end{array}$ & $* * *$ \\
\hline$T C_{\text {Denmark }}$ & $\begin{array}{l}-0.0318 * * * \\
(0.0008)\end{array}$ & $\begin{array}{l}-0.0948 \\
(0.0039)\end{array}$ & $* * *$ & - & & - & \\
\hline$T C_{\text {Estonia }}$ & $\begin{array}{l}-0.0127 \quad * * * \\
(0.0010)\end{array}$ & $\begin{array}{l}-0.0380 \\
(0.0031)\end{array}$ & $* * *$ & - & & - & \\
\hline$T C_{\text {Finland }}$ & $\begin{array}{l}-0.0124 * * * \\
(0.0004)\end{array}$ & $\begin{array}{r}-0.0370 \\
(0.0015)\end{array}$ & $* * *$ & - & & - & \\
\hline$T C_{\text {Germany }}$ & $\begin{array}{l}-0.0129 * * * \\
(0.0002)\end{array}$ & $\begin{array}{l}-0.0384 \\
(0.0013)\end{array}$ & $* * *$ & - & & - & \\
\hline$T C_{\text {Latvia }}$ & $\begin{array}{l}-0.0353 \quad * * * \\
(0.0014)\end{array}$ & $\begin{array}{l}-0.1053 \\
(0.0055)\end{array}$ & $* * *$ & - & & - & \\
\hline$T C_{\text {Lithuania }}$ & $\begin{array}{l}-0.0190 * * * \\
(0.0012)\end{array}$ & $\begin{array}{l}-0.0567 \\
(0.0040)\end{array}$ & $* * *$ & - & & - & \\
\hline$T C_{\text {Poland }}$ & $\begin{array}{l}-0.0140 * * * \\
(0.0005)\end{array}$ & $\begin{array}{l}-0.0417 \\
(0.0019)\end{array}$ & $* * *$ & - & & - & \\
\hline$T C_{\text {Russia }}$ & $\begin{array}{l}-0.0035 \quad * * * \\
(0.0012)\end{array}$ & $\begin{array}{l}-0.0104 \\
(0.0038)\end{array}$ & $* * *$ & - & & - & \\
\hline$T C_{\text {Sweden }}$ & $\begin{array}{l}-0.0102 * * * \\
(0.0006)\end{array}$ & $\begin{array}{l}-0.0305 \\
(0.0023)\end{array}$ & $* * *$ & - & & - & \\
\hline$E N V B N$ & $\begin{array}{l}0.0726 * * * \\
(0.0184)\end{array}$ & $\begin{array}{r}0.2171 \\
(0.0557)\end{array}$ & $* * *$ & $\begin{array}{r}-0.0903 \\
(0.0304)\end{array}$ & $* * *$ & $\begin{array}{c}-0.0088 \\
(0.0042)\end{array}$ & $* *$ \\
\hline$M A L E$ & $0.0694 * *$ & 0.2066 & $* *$ & 0.2850 & $* * *$ & 0.0279 & $* *$ \\
\hline
\end{tabular}




\begin{tabular}{|c|c|c|c|c|c|c|c|c|}
\hline \multirow{3}{*}{ HINC } & \multicolumn{2}{|l|}{$(0.0307)$} & \multicolumn{2}{|l|}{$(0.0908)$} & \multicolumn{2}{|l|}{$(0.0583)$} & \multicolumn{2}{|l|}{$(0.0110)$} \\
\hline & 0.1805 & $* * *$ & 0.5396 & $* * *$ & & \multirow{2}{*}{\multicolumn{2}{|c|}{ - }} \\
\hline & $(0.0321)$ & & $(0.0979)$ & & & & & \\
\hline \multirow{2}{*}{$H I N C^{2}$} & -0.0132 & $* *$ & -0.0395 & $* *$ & \multirow{2}{*}{\multicolumn{2}{|c|}{ - }} & \multirow{2}{*}{\multicolumn{2}{|c|}{-}} \\
\hline & $(0.0055)$ & & $(0.0164)$ & & & & & \\
\hline \multirow{2}{*}{ HHKIDS } & \multirow{2}{*}{\multicolumn{2}{|c|}{-}} & \multirow{2}{*}{-} & & -0.2477 & $* * *$ & -0.0242 & $* * *$ \\
\hline & & & & & $(0.0548)$ & & $(0.0094)$ & \\
\hline \multirow{2}{*}{$A G E$} & \multirow{2}{*}{\multicolumn{2}{|c|}{-}} & \multirow{2}{*}{\multicolumn{2}{|c|}{-}} & -0.4752 & $* * *$ & -0.0433 & $* * *$ \\
\hline & & & & & $(0.1226)$ & & $(0.0097)$ & \\
\hline \multirow{2}{*}{$A G E^{2}$} & \multirow{2}{*}{\multicolumn{2}{|c|}{-}} & \multirow{2}{*}{\multicolumn{2}{|c|}{-}} & 0.0947 & $* * *$ & 0.0095 & $* *$ \\
\hline & & & & & $(0.0132)$ & & $(0.0038)$ & \\
\hline \multirow{2}{*}{$E D U_{2}$} & \multirow{2}{*}{\multicolumn{2}{|c|}{-}} & \multirow{2}{*}{-} & & -0.6938 & $* * *$ & -0.0657 & $* * *$ \\
\hline & & & & & $(0.1143)$ & & $(0.0232)$ & \\
\hline \multirow{2}{*}{$E D U_{3}$} & \multirow{2}{*}{\multicolumn{2}{|c|}{-}} & \multirow{2}{*}{-} & & -0.7958 & $* * *$ & -0.0749 & $* * *$ \\
\hline & & & & & $(0.1155)$ & & $(0.0265)$ & \\
\hline \multirow{2}{*}{$E D U_{4}$} & \multirow{2}{*}{-} & & \multirow{2}{*}{-} & & -1.1835 & $* * *$ & -0.1006 & $* * *$ \\
\hline & & & & & $(0.1188)$ & & $(0.0370)$ & \\
\hline \multirow{2}{*}{$B O C C$} & 0.3062 & $* * *$ & 1.0438 & $* * *$ & -0.5248 & $* * *$ & -0.0470 & $* *$ \\
\hline & \multicolumn{2}{|l|}{$(0.0542)$} & $(0.2112)$ & & $(0.1167)$ & & $(0.0183)$ & \\
\hline \multirow{2}{*}{$\alpha$} & 2.4807 & $* * *$ & & & & & & \\
\hline & $(0.0434)$ & & & & & & & \\
\hline Log-likeli & & & & & $-33,896.71$ & & & \\
\hline (constant & & & & & & & & \\
\hline Log-likeli & & & & & $-13,463.95$ & & & \\
\hline $\mathrm{AIC} / n$ & & & & & 3.0374 & & & \\
\hline McFadder & $o-R^{2}$ & & & & 0.6028 & & & \\
\hline$n$ (observa & & & & & 8,893 & & & \\
\hline$k$ (parame & & & & & 42 & & & \\
\hline
\end{tabular}


Table 3. Descriptive statistics of the number of trips and the associated welfare measures for the current situation and the simulated improvement scenario ${ }^{38}$

\begin{tabular}{|c|c|c|c|c|c|c|c|c|c|c|}
\hline & Denmark & Estonia & Finland & Germany & Latvia & Lithuania & Poland & $\begin{array}{l}\text { Russia } \\
\text { (coastal) }\end{array}$ & Sweden & Total \\
\hline $\begin{array}{l}\text { Adult population } \\
\text { (millions) }\end{array}$ & 4.2668 & 1.0493 & 4.2146 & 67.2119 & 1.6319 & 2.3476 & 30.5180 & 6.0306 & 7.3794 & 124.6502 \\
\hline \multirow{2}{*}{$\begin{array}{l}\text { Predicted probability } \\
\text { of participation }\end{array}$} & 0.9874 & 0.9602 & 0.9068 & 0.9510 & 0.9184 & 0.7512 & 0.9319 & 0.1286 & 0.9722 & 0.9034 \\
\hline & {$[0.0501]$} & {$[0.0855]$} & {$[0.1787]$} & {$[0.0972]$} & {$[0.1495]$} & {$[0.2840]$} & {$[0.1279]$} & {$[0.0902]$} & [0.0918] & {$[0.0620]$} \\
\hline \multirow{2}{*}{$\begin{array}{l}\text { Predicted probability } \\
\text { of } 0 \text { trips }\end{array}$} & 0.4262 & 0.5341 & 0.5038 & 0.7141 & 0.5951 & 0.6815 & 0.7518 & 0.9251 & 0.3699 & 0.6925 \\
\hline & {$[0.1823]$} & {$[0.0982]$} & {$[0.1660]$} & {$[0.1694]$} & {$[0.2198]$} & {$[0.1777]$} & {$[0.1861]$} & {$[0.0533]$} & [0.1174] & {$[0.1027]$} \\
\hline \multirow{2}{*}{$\begin{array}{l}\text { Reported share of } 0 \\
\text { trips }\end{array}$} & 0.3768 & 0.4072 & 0.4980 & 0.7598 & 0.5366 & 0.6563 & 0.6952 & 0.9316 & 0.2866 & 0.6945 \\
\hline & {$[0.4848]$} & {$[0.4915]$} & {$[0.5002]$} & {$[0.4274]$} & {$[0.4988]$} & {$[0.4751]$} & {$[0.4605]$} & {$[0.2525]$} & {$[0.4524]$} & {$[0.2596]$} \\
\hline \multirow{2}{*}{$\begin{array}{l}\text { Predicted average no. } \\
\text { of trips }\end{array}$} & 5.4436 & 1.8561 & 3.1501 & 1.0144 & 2.3892 & 1.5742 & 0.9755 & 0.4237 & 6.2414 & 1.5452 \\
\hline & {$[3.9056]$} & {$[0.8710]$} & {$[2.1511]$} & {$[1.4167]$} & {$[2.2257]$} & {$[2.1828]$} & {$[1.6659]$} & {$[0.3457]$} & {$[3.3469]$} & {$[0.9028]$} \\
\hline \multirow{2}{*}{$\begin{array}{l}\text { Reported average no. } \\
\text { of trips }\end{array}$} & 5.9644 & 1.8289 & 3.9548 & 1.2171 & 2.6422 & 1.6621 & 1.1195 & 0.4647 & 6.4214 & 1.7522 \\
\hline & [15.4424] & {$[5.6251]$} & [19.785] & [10.694] & [7.1686] & {$[5.7720]$} & {$[8.4515]$} & [2.4404] & [13.1368] & {$[6.2373]$} \\
\hline \multirow{2}{*}{$\begin{array}{l}\text { Average consumer } \\
\text { surplus of a single } \\
\text { trip (EUR) }\end{array}$} & $31.4763^{* * *}$ & $78.5992 * * *$ & $80.6823^{* * *}$ & $77.6064 * * *$ & $28.3449 * * *$ & $52.5731^{* * *}$ & $71.5118^{* * *}$ & $288.1049^{* * *}$ & $97.9854 * * *$ & $84.9217^{* * *}$ \\
\hline & $(29.878-33.068)$ & $(67.060-90.248)$ & $(75.942-85.454)$ & $(74.856-80.337)$ & $(26.074-30.610)$ & $(46.273-58.866)$ & (66.532-76.539) & $(89.051-489.530)$ & $(85.977-109.91)$ & (75.054-94.849) \\
\hline \multicolumn{11}{|c|}{ Welfare measures - current situation } \\
\hline \multirow{2}{*}{$\begin{array}{l}\text { Total consumer } \\
\text { surplus (billion EUR) }\end{array}$} & $0.7221 * * *$ & $0.1495^{* * *}$ & $1.0427 * * *$ & $5.1423 * * *$ & $0.1079 * * *$ & $0.1915^{* * *}$ & $2.0664 * * *$ & $0.9436^{* * *}$ & $4.4328 * * *$ & $14.7992 * * *$ \\
\hline & $(0.626-0.809)$ & $(0.115-0.180)$ & $(0.772-1.212)$ & $(3.909-5.837)$ & $(0.081-0.129)$ & $(0.119-0.260)$ & $(1.495-2.463)$ & $(0.078-3.167)$ & $(3.550-5.266)$ & $(11.301-18.029)$ \\
\hline \multicolumn{11}{|c|}{ Welfare measures - simulated scenario } \\
\hline \multirow{2}{*}{$\begin{array}{l}\text { Partial effect of } \\
\text { ENVBN }^{39}\end{array}$} & $0.4030^{* * *}$ & $0.1425^{* * *}$ & $0.2490^{* * *}$ & $0.0790^{* * *}$ & $0.1889 * * *$ & $0.1421^{* * *}$ & $0.0767^{* * *}$ & $0.0988^{* * *}$ & $0.4665^{* * *}$ & $0.1223 * * *$ \\
\hline & $(0.205-0.604)$ & $(0.076-0.208)$ & $(0.133-0.367)$ & $(0.041-0.118)$ & $(0.102-0.278)$ & $(0.080-0.209)$ & $(0.039-0.116)$ & $(0.015-0.254)$ & $(0.241-0.698)$ & $(0.065-0.181)$ \\
\hline \multirow{2}{*}{$\begin{array}{l}\text { Total simulated } \\
\text { consumer surplus } \\
\text { (billion EUR) }\end{array}$} & $0.7762 * * *$ & $0.1612 * * *$ & $1.1274 * * *$ & $5.5544 * * *$ & $0.1167^{* * *}$ & $0.2091 * * *$ & $2.2340^{* * *}$ & $1.1152^{* * *}$ & $4.7701 * * *$ & $16.0647 * * *$ \\
\hline & $(0.674-0.874)$ & $(0.125-0.194)$ & $(0.842-1.312)$ & $(4.268-6.346)$ & $(0.089-0.139)$ & $(0.132-0.280)$ & $(1.635-2.678)$ & $(0.098-3.653)$ & $(3.837-5.667)$ & $(12.289-19.666)$ \\
\hline $\begin{array}{l}\text { Absolute change of } \\
\text { the total consumer } \\
\text { surplus (billion EUR) }\end{array}$ & 0.0540 & 0.0117 & 0.0844 & 0.4106 & 0.0087 & 0.0175 & 0.1670 & 0.1710 & 0.3361 & 1.9687 \\
\hline $\begin{array}{l}\text { Relative change of } \\
\text { the total consumer } \\
\text { surplus (\%) }\end{array}$ & $+7.47 \%$ & $+7.84 \%$ & $+8.10 \%$ & $+7.99 \%$ & $+8.07 \%$ & $+9.13 \%$ & $+8.09 \%$ & $+18.14 \%$ & $+7.59 \%$ & $+8.84 \%$ \\
\hline
\end{tabular}

\footnotetext{
$3895 \%$ confidence intervals provided in round, standard deviations in square brackets.
}

${ }^{39}$ Average change in the number of trips per person resulting from a unit change in the 5-level perception of the status of the Baltic Sea environment. 